\title{
Гончаров Май Васильевич (1923-1989) - кадровый военный, ученый, педагог
}

\author{
Р. Е. Рогозина $\bowtie$ \\ Воронежский государственный университет, Российская Федерация \\ (394018, г. Воронеж, Университетская пл., 1)
}

\begin{abstract}
Аннотация: Статья посвящена памяти Мая Васильевича Гончарова, уроженца города Воронежа, окончившего школу в Новосибирске, артиллерийское училище - в Томске, закончившего военную службу в Прибалтийском военном округе, около 33 лет проработавшего преподавателем, заведующим кафедрой, деканом в Воронежском государственном университете и оставившего добрую память о себе в сердцах студентов, коллег, научного сообщества.

Ключевые слова: служба, учеба, научные интересы, читаемые курсы, оценка земель, руководство, публикации.

Для цитирования: Рогозина Р.Е. М. В. Гончаров (1923-1989) - кадровый военный, ученый, педагог // Вестник Воронежского государственного университета. Серия: География, Геоэкология, 2021, № 2, c. 91-94. DOI: https://doi.org/10.17308/geo.2021.2/3453
\end{abstract}

Май Васильевич Гончаров родился в городе Воронеже 14 декабря 1923 года в семье служащего. Его отец был преподавателем истории КПСС, а мама - домохозяйкой. Среднюю школу он закончил в Новосибирске. В этом городе во время войны вся семья была в эвакуации. Оттуда же он был призван в Советскую армию. Во время срочной службы М.В.Гончаров проходил обучение в артиллерийском училище в городе Томске. После его окончания в 1942 году и до конца Великой Отечественной войны сражался на ее фронтах: Сталинградском, Украинском, Прибалтийском. В ходе боев под Сталинградом был ранен. После войны окончил Высшую артиллерийскую школу в городе Ленинграде и до 5 августа 1956 года, вплоть до увольнения в запас по сокращению вооруженных сил, был кадровым военным. Завершил службу в армии Май Васильевич в звании майора в должности начальника штаба отдельного артдивизиона Прибалтийского военного округа. Был награжден правительственными наградами: орденом «Отечественной войны» 2 и 1 степени, орденом «Красной звезды»; медалями «За оборону Сталинграда»; «30 лет Советской Армии»; «За победу над Германией»; «За боевые заслуги».
Находясь на службе в вооруженных силах, он с отличием заочно окончил Воронежский государственный университет. С 1 сентября 1956 года начал работать преподавателем на кафедре экономической географии географического факультета ВГУ. Приехал в Воронеж Май Васильевич уже с семьей: женой и двумя сыновьями. Через пять лет он был зачислен в аспирантуру к профессору Г.Т. Гришину по специальности «экономическая география» без сдачи вступительных экзаменов. По окончании обучения снова вернулся на место преподавателя кафедры. В 1965 году защитил кандидатскую диссертацию на тему «География сельского хозяйства Белгородской области / вопросы сельскохозяйственного районирования» с присвоением ему ученой степени кандидата географических наук.

Организаторские способности, которые проявились у Мая Васильевича еще во время службы в армии, пригодились ему и в гражданской жизни. С 20 августа 1966 года кандидат географических наук, старший преподаватель кафедры экономической географии М.В. Гончаров был избран деканом географического факультета. Решением Высшей аттестационной комиссии от

(C) Рогозина Р.Е., 2021

$\triangle$ Рогозина Римма Евгеньевна, e-mail: rrogozina@bk.ru

Контент доступен под лицензией Creative Commons Attribution 4.0 License. 
17 января 1968 года Май Васильевич утвержден в звании доцента по кафедре «Экономическая география». С 1975 года временно, на период болезни доцента Н.Н. Бельского, а со следующего года - постоянно избран на должность заведующего кафедрой экономической географии, в которой он проработал до 1982 года, когда его сменил доцент Ю. В. Поросенков. Сконца 1978 годаГончаров М.В. во второй раз был избран деканом географического факультета [2]. Закончил свою трудовую деятельность в университете Май Васильевич в должности доцента кафедры экономической географии (0,25 ставки) в 1989 году.

Научные интересы М.В.Гончарова связаны с сельскохозяйственным районированием и с серьезной работой по экономической оценке земель. Исследования проводились совместно с физико-географами факультета и сотрудниками НИИ сельского хозяйства Центрально-Черноземной полосы им. В. В. Докучаева. По этим проблемам он принимал участие в работе Всесоюзного совещания по учету и качественной оценке земель.

Под руководством и по инициативе доцента М.В. Гончарова в 1970-е годы на факультете была создана и на протяжении многих лет плодотворно функционировала лаборатория по экономической оценке земель. Выполненные этим подразделением на хоздоговорных началах исследования в хозяйствах Павловского, Аннинского и Лискинского районов Воронежской области получили высокую оценку научных и хозяйственных организаций.

Как опытный педагог и администратор Май Васильевич принимал участие в работе Научно-методического совета по географии при Минвузе СССР. В качестве заместителя председателя участвовал в заседаниях секции «Экономическая география», что способствовало образованию прочных научных связей с педагогической общественностью вузов страны. На географическом факультете ВГУ кафедрой экономгеографии было организовано и успешно проведено выездное заседание секции Научно-методического совета. М.В. Гончаров много лет руководил работами по составлению учебного плана «2030-География» и участвовал в работе Головного совета по географическим наукам при Минвузе СССР, выступал оппонентом по кандидатским и рецензентом по докторским диссертациям на Ученом совете МГУ.

Основные научные публикации Мая Васильевича приходятся на 60-80-е годы и представлены в монографиях, журналах, сборниках.
1. Вопросы экономической оценки земель / Известия Воронеж. отд. Геогр. о-ва СССР. Вып. 3. Воронеж, 1961.

2. Объекты исследования при крупномасштабном изучении и дробном районировании сельского хозяйства / Известия Воронеж. отд. Геогр. о-ва СССР. Вып. 4. Воронеж, 1962.

3. Ландшафтно-типологические исследования и вопросы экономической оценки земель. Учет и оценка сельскохозяйственных земель (в соавторстве). Москва: МГУ, 1963.

4. Белгородская область. Экономико-географическое районирование Черноземного Центра / Под ред. Г. Т. Гришина. Воронеж, 1963.

5. Вопросы методики определения рентабельности лесных полос / Научные записки Воронеж. отд. Геогр. о-ва СССР, 1967.

6. Районы свеклосахарного производства ЦЧР / Научные записки Воронеж. отд. Геогр. о-ва СССР. Воронеж, 1967.

7. Природно-экономические вопросы рационального использования земель // Вопросы ландшафтной географии (в соавторстве), 1969.

8. Каменная степь. Опыт ландшафтно-типологической характеристики (в соавторстве). Воронеж, 1971.

9. Некоторые вопросы экономической оценки земель // Проблемы почвоведения, агрохимии и мелиорации почв Русской равнины, 1974.

10. Природные ресурсы района, проблемы их использования и охраны. Проблемы территориальной организации производительных сил ЦЧР, 1977.

11. Вопросы изучения территориальных сочетаний естественных ресурсов как глобальная и региональная проблема // Методологические проблемы исследования основного социально-экономического района, 1979.

12. Проблемы географии сельского хозяйства СССР // Вестник МГУ. Серия 5. География, 1982, № 2.

В своих работах М.В.Гончаров представил разработанную им географическую методику экономической оценки качества земель («оценка поля»), методику определения агроэкономической эффективности защитного лесоразведения (в соавторстве с А.И. Нестеровым и Н.Г. Петровым), выделил основные формы использования земель в Воронежской области и обосновал понятие «типы использования земель», факторный метод их определения (в соавторстве с Л.В. Баранович), представил земельно-оценочное районирование как резерв повышения эффективности 
АПК, предложил свое понимание вопросов географического изучения территориальных сочетаний естественных ресурсов на региональном уровне [1]. Его исследования часто носили междисциплинарный характер, что позволяло объединять усилия экономико- и физико-географов, почвоведов, экономистов.

Много лет подряд Май Васильевич выполнял общественную работу, как на факультете, так и на уровне университета: был заместителем секретаря и секретарем парткома ВГУ, членом партийного бюро географического факультета.

За время педагогической деятельности на кафедре экономической географии М.В. Гончаров читал базовые курсы: «Экономическая география СССР. Ч.1. Экономические районы», «Методика полевых экономико-географических исследований», «География промышленности», а также им были освоены спецкурсы: «Экономическая оценка естественных ресурсов», «Основные проблемы экономической географии» (для физико-географов), «География сельского хозяйства с основами сельскохозяйственного производства». В помощь студентам были разработаны и опубликованы программы и методические указания по читаемым дисциплинам.

В студенческой среде Май Васильевич пользовался заслуженным уважением, хотя отличался требовательностью и принципиальностью. Выпускники факультета вспоминают его содержательные и логически выстроенные лекции, производственные и учебные практики, которыми он руководил, беседы по патриотическому воспитанию.

М.В. Гончаров на всю свою жизнь сохранил офицерскую выправку, дисциплинированность и высокий уровень культуры общения, организаторские способности и доброе отношение к коллегам и студентам. Таким он остается в памяти тех, кому посчастливилось у него учиться, с ним работать и заниматься научными исследованиями.

\section{СПИСОК ЛИТЕРАТУРЫ}

1. Поросенков Ю.В., Анисимова Л.В., Баранович Л.В. М.В.Гончаров (1923-1989). Ученый и общественный деятель // Вестник Воронежского государственного университета. Серия: География. Геоэкология, 2004, № 2, c. 117-119.

2. Федотов В.И. К столетию изучения географии в Воронежском государственном университете (19192019) // Вестник ВГУ. Серия: География. Геоэкология, 2020, № 2, с. 81-95. DOI: https://doi.org/10.17308/ geo.2020.2/2890.

Конфликт интересов: Автор декларирует отсутствие явных и потенциальных конфликтов интересов, связанных с публикацией настоящей статьи.

Поступила в редакцию 30.03.2021 Принята к публикачии 28.05.2021 


\title{
Goncharov May Vasilievich (1923-1989) - Career Soldier, Scientist, Educator
}

\author{
R.E. Rogozina ${ }^{\square}$ \\ Voronezh State University, Russian Federation \\ (1, Universitetskaya Pl., Voronezh, 394018)
}

\begin{abstract}
The article is dedicated to the memory of May Vasilievich Goncharov, a native of the city of Voronezh. He graduated from school in Novosibirsk, an artillery school in Tomsk, completed his military service in the Baltic Military District. He worked as a teacher, head of department, dean at Voronezh State University for about 33 years and left a good memory of himself in the hearts of students, colleagues, and the scientific community.

Key words: military service, education, scientific interests, classes delivered, land assessment, leadership, publications.

For citation: Rogozina R.E. M.V. Goncharov (1923-1989) - Career Soldier, Scientist, Educator. Vestnik Voronezskogo gosudarstvennogo universiteta. Seria: Geografia. Geoekologia, 2021, no. 2, pp. 91-94. (In Russ.). DOI: https://doi.org/10.17308/geo.2021.2/3453
\end{abstract}

\section{REFERENCES}

1. Porosenkov Y.V., Anisimova L. V., Baranovich L.V. Goncharov M.V. (1923-1989). Uchenyj i obshchestvennyj deyatel' [Goncharov M.V. (1923-1989). Scientist and social activist]. Vestnik Voronezhskogo gosudarstvennogo universiteta. Seria: Geografia. Geoekologia, 2004, no. 2, pp. 117-119.

2. Fedotov V.I. K stoletiyu izucheniya geografii v Voronezhskom gosudarstvennom universitete (1919-2019) [By the century of studying geography at Voronezh State

Рогозина Римма Евгеньевна

кандидат географических наук, заведующий кафедрой социально-экономической географии и регионоведения факультета географии, геоэкологии и туризма Воронежского государственного университета, г. Воронеж, Российская Федерация, ORCID: 0000-00028959-6511, e-mail: rrogozina@bk.ru
University (1919-2019)]. Vestnik Voronezskogo gosudarstvennogo universiteta. Seria: Geografia. Geoekologia, 2020, no. 2, pp. 81-95. (In Russ.) DOI: https://doi. org/10.17308/geo.2020.2/2890.

Conflict of interests: The author declares no information of obvious and potential conflicts of interest related to the publication of this article

Received: 30.03 .2021

Accepted: 28.05.2021

Rimma E. Rogozina

Cand. (Geogr.) Sci., Associate Professor, the Head of the Department of Socio-Economic Geography and Regional Studies, Faculty of Geography, Geoecology and Tourism, Voronezh State University, Voronezh, Russian Federation, ORCID: 0000-0002-8959-6511, e-mail: rrogozina@bk.ru

(C) Rogozina R.E., 2021

$\triangle$ Rimma E. Rogozina, e-mail: rrogozina@bk.ru

The content is available under Creative Commons Attribution 4.0 License. 